\title{
Isovaleric acid is mainly produced by Propionibacterium freudenreichii in Swiss cheese
}

\author{
Anne Thierry ${ }^{\mathrm{a}, *}$, Romain Richoux ${ }^{\mathrm{b}}$, Jean-René Kerjean ${ }^{\mathrm{b}}$ \\ ${ }^{\text {a }}$ Laboratoire de Recherches de Technologie Laitière, INRA., 65 rue de Saint-Brieuc, Rennes Cedex 35042, France \\ ${ }^{\mathrm{b}}$ Institut Technique Français des Fromages, BP 6224, Rennes Cedex 35062, France
}

Received 7 July 2003; accepted 18 February 2004

\begin{abstract}
Isovaleric acid (3-methylbutyric acid) and 2-methylbutyric acid contribute to Swiss cheese flavour. In order to determine the contribution of propionibacteria (PAB) to the production of methylbutyric acids, mini-Swiss cheeses were manufactured with or without PAB as a secondary starter (25 Propionibacterium freudenreichii strains), associated with different cultures of thermophilic lactic starters. In the presence of PAB, the quantity of methylbutyric acids was three to ten times greater, depending on PAB strain,

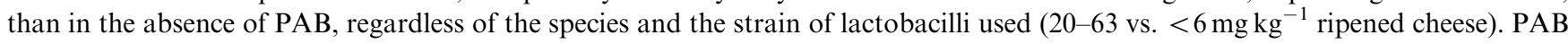
produced methylbutyric acids concomitantly with acetic and propionic acids, then kept on producing methylbutyric acids after propionic fermentation. The increase in salt-in-moisture content of cheese from $1.0 \%$ to $1.8 \%$ induced a strain-dependent inhibition of isovaleric acid production. This study shows that $P$. freudenreichii is the main contributor to methylbutyric acid production in Swiss cheese.
\end{abstract}

(C) 2004 Elsevier Ltd. All rights reserved.

Keywords: Propionibacterium; Isovaleric acid; Swiss-type cheese; Flavour; Thermophilic lactic starter; Salt

\section{Introduction}

Flavour compounds are formed during the cheese ripening process from the enzymatic breakdown of milk protein, fat, lactose and lactate (McSweeney, Nursten, \& Urbach, 1997). However, we have only fragmentary knowledge of the microflora and the pathways involved in the formation of many flavour compounds. To control and diversify cheese flavour, it is necessary to understand how microflora and other factors affect the formation and synthesis pathways for each family of flavour compounds.

3-Methylbutyric acid (actual isovaleric acid) and 2-methylbutyric acid are branched-chain volatile acids involved in Swiss cheese flavour (Langler, Libbey, \& Day, 1967; Preininger, Warmke, \& Grosch, 1996). The presence of isovaleric acid is related to the intensity and aromatic richness of several cheeses such as Comté (Berdagué \& Grappin, 1988) and Abondance (Bugaud,

*Corresponding author. Tel.: +33-2-2348-5337; fax: +32-2-23485350.

E-mail address: athierry@rennes.inra.fr (A. Thierry).
Buchin, Hauwuy, \& Coulon, 2001). The concentration of isovaleric acid in Swiss cheeses varies over a large range (from undetectable values up to $100 \mathrm{mg} \mathrm{kg}^{-1}$ cheese) (Patton, 1964; Langler \& Day, 1966; Bosset et al., 1992), with mean values of around $26 \mathrm{~m} \mathrm{~kg}^{-1}$ in French Emmental cheese (Berdagué, Grappin, DelacroixBuchet, \& Chaillet, 1990). In many of the available reports, the term "isovaleric acid" referred to the mixture of 3-methyl-butyric acid and 2-methyl-butyric acid, which were not separated by the chromatographic method used to analyse volatile acids. In this paper, the term "methylbutyric acids" was preferred to refer to the mixture of both acids. 3-Methylbutyric acid and 2-methylbutyric acid originate from leucine and isoleucine catabolism, respectively, via a first step of transamination followed by oxidation steps.

The microflora that produce methylbutyric acids in Swiss cheese have never been completely clarified. Most species of Swiss cheese ecosystem are able to produce methylbutyric acids in vitro, as recently shown using resting cells of different species incubated in the presence of leucine and $\alpha$-ketoglutarate: Lactobacillus helveticus, Lactobacillus delbrueckii subsp. lactis (Yvon \& Rijnen, 
2001; Helinck, Moreau, \& Yvon, 2001), Propionibacterium freudenreichii (Thierry, Maillard, \& Yvon, 2002), and Lactobacillus paracasei, a non-starter bacterium (Tammam, Williams, Noble, \& Lloyd, 2000; Williams, Noble, \& Banks, 2001; Tavaria, Dahl, Carballo, \& Malcata, 2002). However, methylbutyric acids appeared only in samples containing $P$. freudenreichii in cream fermented by Swiss cheese starter organisms both singly and in combinations at temperature and $\mathrm{pH}$ simulating cheese ripening conditions (Biede, Paulsen, Hammond, \& Glatz, 1979). Similarly, methylbutyric acid were found mainly produced by $P$. freudenreichii (one strain tested) in small-scale Swiss cheeses (Thierry \& Maillard, 2002). Our hypothesis was that $P$. freudenreichii is the organism responsible for the majority of the methylbutyric acid production in Swiss-type cheese. To check this hypothesis, we determined the production of methylbutyric acids in small-scale Swiss cheeses manufactured with or without the addition of $P$. freudenreichii as secondary starter (25 strains tested), in the presence of different combinations of thermophilic lactic starters. We showed that methylbutyric acids were mainly produced by $P$. freudenreichii in Swiss cheese and that the production was strain-dependent.

\section{Materials and methods}

\subsection{Starters}

Several thermophilic lactic starters and PAB starters were used. Pure cultures of L. helveticus (ITGLH1, ITGLH77 and LHRR), L. delbrueckii subsp. lactis (ITGLL14, ITGLL51), S. thermophilus (ITGST49/50) and $P$. freudenreichii (ITGP1, ITGP3, ITGP4, ITGP5, ITGP6, ITGP8, ITGP9, ITGP10, ITGP11, ITGP12, ITGP13, ITGP14, ITGP15, ITGP16, ITGP17, ITGP18, ITGP19, ITGP20, ITGP21, ITGP22, ITGP23, ITGP24, ITGP25) were obtained from the collection of the Institut Technique Français du Fromage (35062 Rennes, France). P. freudenreichii strains A and B are two industrial strains from the TL collection (Laboratoire de Recherches de Technologie Laitière, INRA, 35042 Rennes, France), and L. helveticus LHRR was an industrial strain from UCC Culture Collection (Cork, Ireland). LH100 (L. helveticus and L. delbrueckii subsp. lactis) and $S$. thermophilus TA060 were obtained from Rhodia-Food (Dangé Saint-Romain, France).

\subsection{Cheese manufacture}

Small scale $(1 / 100)$ experimental Swiss cheeses were manufactured from thermised $\left(65^{\circ} \mathrm{C}, 20 \mathrm{~s}\right)$ and microfiltered milk by the Institut Technique Français des Fromages according to a standardised cheese-making process that was previously detailed (Richoux \&
Kerjean, 1995; Richoux, Faivre, \& Kerjean, 1998). The starters were composed of $S$. thermophilus TA060, L. helveticus and/or L. delbrueckii subsp. lactis, with or without the addition of $P$. freudenreichii as secondary starters. Briefly, the milk was ripened with starters at $32^{\circ} \mathrm{C}$ for $1 \mathrm{~h}$ and coagulated by the addition of calf rennet (Chr Hansen, Beaune, France). When the desired firmness was reached, the gel was cut into pieces of $4 \mathrm{~mm}$, stirred $15 \mathrm{~min}$ and cooked at $53.5^{\circ} \mathrm{C}$ for $45 \mathrm{~min}$. The pressing step $(6 \mathrm{~h})$ and the acidification step (14h) were conducted in thermostated ovens at $48^{\circ} \mathrm{C}$ and $36^{\circ} \mathrm{C}$, respectively, in order to mimic the cooling rate of the centre of a full-size Emmental wheel. Cheeses were then cooled and salted in a NaCl-saturated brine at $7{ }^{\circ} \mathrm{C}$ for 3.5 or $21 \mathrm{~h}$ (to obtain, respectively, $1 \%$ and $1.8 \%$ salt-in-moisture). Each cheese was manufactured in triplicate. Cheeses were divided into four pieces $(200 \mathrm{~g}$ each) before waxing. Cheeses were ripened at $11^{\circ} \mathrm{C}$ (cold room) for 21 days and then at $24^{\circ} \mathrm{C}$ (warm room) for 28 days. One piece was used for all the analyses made at each ripening stage (cheeses entering in the warm room, and at different times of ripening in the warm room: $\mathrm{d} 14$ and $\mathrm{d} 28$ (end) for all cheeses, and two added ripening stages (d7 and d21) for some cheeses, in order to determine the time course of short-chain carboxylic acid production.

The data presented in this manuscript refer to cheeses made using the same standardised protocol from 1991 to 1996, for the earlier studies of Richoux and Kerjean (1995), Richoux et al. (1998). These experiments aimed at screening $\mathrm{PAB}$ strains for their ability to produce acetate, propionate and opening in cheese (Richoux et al., 1998). Volatile acids (from acetic to hexanoic acids) were analysed at that time. Although a peak of "isovaleric acid" (2-methyl + 3-methylbutyric acids) was detected and integrated in the chromatograms of volatile acids, these data were not systematically dealt with at that time. Among these different sets of data, we selected: (1) all the trials in which different strains of thermophilic lactobacilli were used as starters (with or without added PAB); (2) trials carried out with the same strains of lactic starters (TA060 + LH100) and various PAB strains, at two levels of salt-in-moisture (Richoux et al., 1998).

\subsection{Biochemical analyses}

Composition of ripened cheeses was determined by classical methods as previously described (Richoux \& Kerjean, 1995). Short-chain carboxylic acids were extracted by a $50-50$ mixture $(\mathrm{V} / \mathrm{V})$ of diethyl ether and petroleum ether at acidic $\mathrm{pH}$ and analysed by gas chromatography as previously described (Berdagué, Jeunet, \& Grappin, 1987). The chromatographic conditions did not make it possible to separate 2-methylbutyric acid from 3-methylbutyric acid, which are both 
referred to as methylbutyric acids in the present study. The detection limit of methylbutyric acids in cheese was around $5 \mathrm{mg} \mathrm{kg}^{-1}$, resulting in high standard deviations for cheese containing small amounts of this acid.

\subsection{Microbiological analyses}

Total microflora in cheese milk were enumerated on plate count agar (PCA, Biokar, Beauvais, France) incubated at $30^{\circ} \mathrm{C}$ for 3 days, PAB on YEL (Malik, Reinbold, \& Vedamuthu, 1968) incubated at $30^{\circ} \mathrm{C}$ for 6 days. Due to the reduced size of cheese samples, only some cheeses were microbiologically controlled: nonstarter lactic acid bacteria, which can grow in the cheese during the ripening, were enumerated on $\mathrm{FH}$ agar (Isolini, Grand, \& Glättli, 1990) incubated at $30^{\circ} \mathrm{C}$ for 3 days or on MRS agar incubated at $15^{\circ} \mathrm{C}$ for 14 days (Thierry, Salvat-Brunaud, \& Maubois, 1999).

\subsection{Data analysis}

Data for the concentration of methylbutyric acids of triplicate cheeses were used for statistical analysis. Analyses of variance (ANOVA) were performed by using the General Linear Model procedure of Statgraphics Plus (Statistical Graphic Corp., Englewood Cliffs, NJ, USA) to determine the effect of different factors on the production of methylbutyric acids. In a first set of experiments (14 cheeses made in triplicate), we evaluated the effect of the combination of strains (lactobacilli and PAB) used in cheese manufacture on the production of methylbutyric acids (Fig. 1). In a second set of experiments (52 cheeses made in triplicate), we determined the effect of PAB strain (25 strains tested and a control cheese without PAB), of salt level (1.0\% and $1.8 \%$ salt-in-moisture), and of the strainsalt interaction on the production of methylbutyric acids (Fig. 3). The Fisher's least significant difference (LSD) test was used to determine which means were significantly different from which others (at a 95\% confidence level).

\section{Results}

\subsection{Cheese composition and microbiological content}

The gross composition of the cheeses was consistent with the expected values. After $28 \mathrm{~d}$ of ripening at $24^{\circ} \mathrm{C}$ (warm room), they contained $63.3 \pm 0.76 \%$ total solids, $46 \pm 1.3 \%$ fat in dry matter and $51.9 \pm 0.7 \%$ moisture in non-fat cheese.

Thermisation and microfiltration of cheese milk decreased the level of total counts to less than 10 colony-forming units (cfu) per $10 \mathrm{ml}$ milk. Non-starter lactic acid bacteria counts in cheeses were generally

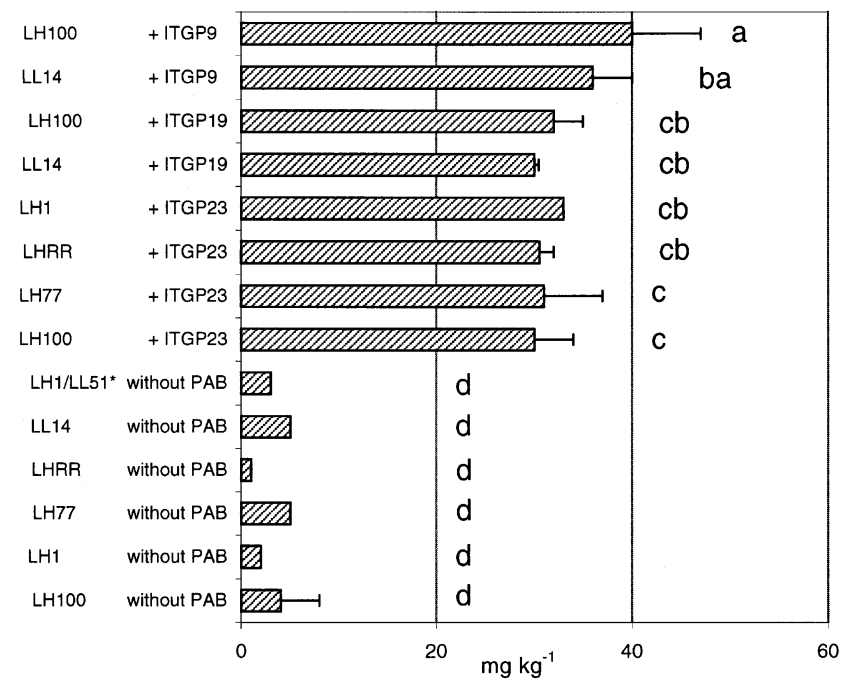

Fig. 1. Effect of the combination of starter strains (codes of species: LH: L. helveticus, LL: L. delbrueckii subsp. lactis and ITGP: $P$. freudenreichii) used in the manufacture of mini Swiss cheeses, on the amount of methylbutyric acids produced after $28 \mathrm{~d}$ of ripening in the warm room. Bars and error-bars show the means and standard deviations of triplicate cheeses. Values with the same letter do not significantly differ according to the LSD test $(P<0.05)$. In cheese marked by an asterisk, $S$. thermophilus was ITGST49/50 instead of TA060.

$<10^{6} \mathrm{cfu} / \mathrm{g}$ cheese at the end of ripening. In control cheeses made without the addition of PAB, counts of contaminating $\mathrm{PAB}$ were $<10^{6} \mathrm{cfu} / \mathrm{g}$ and propionic acid was $<50 \mathrm{mg} \mathrm{kg}^{-1}$ at the end of ripening (data not shown).

\subsection{Effect of the presence of propionibacteria on the production of methylbutyric acids}

In order to determine the contribution of PAB to the production of methylbutyric acids in Swiss cheese, the concentration of methylbutyric acids was compared at the end of ripening in the warm room (d28) in 14 miniSwiss cheeses manufactured in triplicate using two strains of $S$. thermophilus (TA060 and ITGST49/50) and different combinations of lactobacilli (six cultures) and PAB (three strains). Cheeses without PAB were also included. The detail of the tested combinations is given in Fig. 1.

Differences in methylbutyric acids content between individual cheeses were investigated by one-way ANOVA. The combination of starter strains (i.e. one or two lactobacilli strain(s) associated or not to one PAB strain) significantly affected $(P<0.001)$ the production of methylbutyric acids. According to the LSD test, the concentration of methylbutyric acids at $\mathrm{d} 28 \mathrm{did}$ not significantly $(P<0.05)$ differed within the group of cheeses manufactured without addition of $\mathrm{PAB}$, regardless of the species and strains constituting the lactic 
starter, and was significantly lower than in the presence of PAB (Fig. 1). In the presence of PAB, the concentration of methylbutyric acids was about ten times greater than in the absence of $\mathrm{PAB}$, with average amounts of $33 \pm 3.5$ and $3 \pm 1.6 \mathrm{mg} \mathrm{kg}^{-1}$, respectively. For cheeses containing the same strain of lactic starter (LH100) and associated with different PAB strains, significant differences in methylbutyric acid concentration $(P<0.05)$ were observed between the cheeses. On the contrary, for cheeses containing same PAB strain and associated with different lactic starters, no significant differences in methylbutyric acids concentration were observed between the cheeses (Fig. 1). These results show that methylbutyric acids were mainly produced by $\mathrm{PAB}$ in these cheeses.

\subsection{Effect of PAB strain on methylbutyric acids production}

In order to study in detail the effect of PAB strain on the amount of methylbutyric acids produced, mini-Swiss cheeses manufactured using the same strains of thermophilic lactic starter (S. thermophilus TA060 and lactobacilli LH100) and different PAB strains (25 strains tested and a control cheese without PAB) were analysed for their volatile acid content during the ripening in the warm room ( $28 \mathrm{~d})$.

We first determined the time course of short-chain carboxylic acid production in cheese, to assess the possible relationships between methylbutyric acid production and propionic fermentation (i.e. the production of acetic and propionic acids from lactic acid). The greater part of propionic fermentation $(>80 \%$, i.e. more than $6.5 \mathrm{~g}$ propionic acid per $\mathrm{kg}$ cheese) was achieved within the first two weeks of ripening in the warm room, by 20 out of 25 PAB strains (data not shown). The time course of short-chain acid production is illustrated with Fig. 2 for six strains, chosen to show standard and extreme behaviours (ITGP20 and ITGP21, for instance, were both "fast-fermenting" strains, i.e. the ones having early completed propionic fermentation, ITGP5 was the slowest fermenting strain, whereas the three other strains exhibited an intermediate behaviour). Methylbutyric acids were produced from the beginning of ripening in the warm room, as shown in Fig. 2 for six strains. A significant correlation $(P<0.001)$ was found between the concentration of methylbutyric acids and propionic acid (used as an index of growth and fermentation)
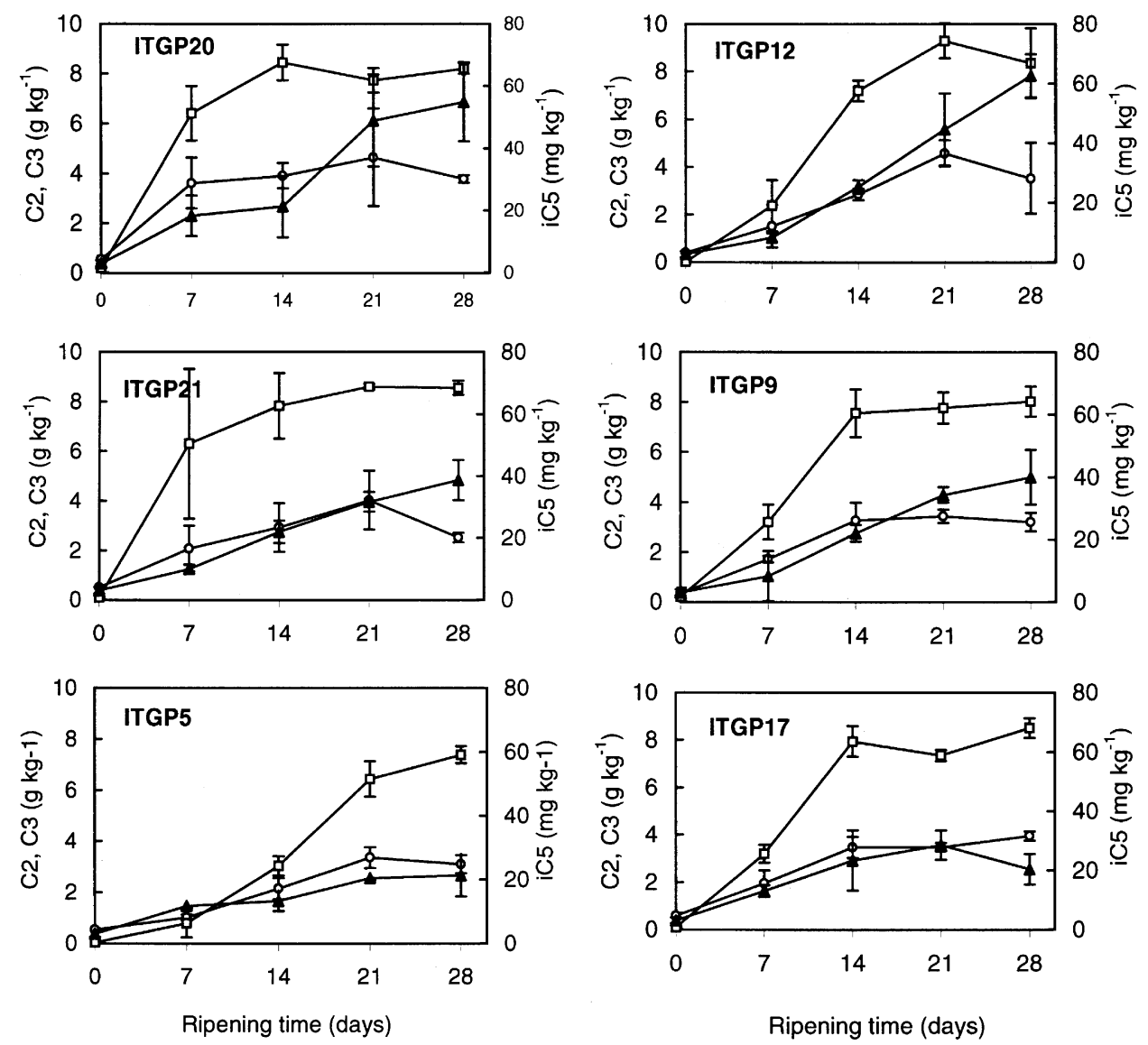

Fig. 2. Time course of propionic $(\mathrm{C} 3, \square)$, acetic $(\mathrm{C} 2, \bigcirc)$ and methylbutyric acid (iC5, $\mathbf{\Delta})$ production during the ripening in the warm room in mini Swiss cheeses inoculated with six strains of $P$. freudenreichii. Labels and error-bars show the means and standard deviations of triplicate cheeses. 
$(r=0.720$; calculated from 24 values of propionic and methylbutyric acid contents at $\mathrm{d} 7$ or d14). However, this low value of $r$ (i.e. $r^{2}=0.518$ ) indicates that only half of the variations in methylbutyric acid content could be explained by the variations in propionic acid content. In other words, the differences of methylbutyric acid production between $\mathrm{PAB}$ strains were not only due to differences in growth and propionic fermentation during this first period of ripening. During the last $14 \mathrm{~d}$ in the warm room (from d15 to d28), PAB strains behaved very differently in relation to methylbutyric acid production, whereas most strains neither grew nor produced propionate anymore. Some strains did not produce methylbutyric acids anymore (ITGP17) or produced very small amounts (ITGP5), whereas some others produced large amounts, such as ITGP20 and ITGP12 (Fig. 2). As a consequence, the greatest total amount of methylbutyric acids was not necessarily produced by the "fast-fermenting" strains (i.e. the ones having early completed propionic fermentation). As an example, the strains producing the greatest and the smallest amount of methylbutyric acids after $28 \mathrm{~d}$ in the warm room (ITGP12, $62.7 \mathrm{mg} \mathrm{kg}^{-1}$ and ITGP17, $20.3 \mathrm{mg} \mathrm{kg}^{-1}$, respectively) showed a similar time course of propionic fermentation rate (Fig. 2).

We then compared the production of methylbutyric acids at $\mathrm{d} 14$ and $\mathrm{d} 28$ for 25 PAB strains, at standard level $(1 \%)$ and at a higher level $(1.8 \%)$ of salt-in- moisture. The ANOVA showed that the amount of methylbutyric acids produced at both stages was significantly influenced by the strain of PAB $(P<0.001)$, by the level of salt $(P<0.001)$, and by the interaction $\mathrm{PAB}$ strain/salt $(P<0.01)$. The mean amounts of methylbutyric acids produced by the 25 PAB strains at $1.0 \%$ and $1.8 \%$ salt-in-moisture were $21 \pm 6.8$ and $9 \pm 5.0 \mathrm{mg} \mathrm{kg}^{-1}$ cheese, respectively, at $\mathrm{d} 14$, and $37 \pm 11.7$ and $25 \pm 14.0 \mathrm{mg} \mathrm{kg}^{-1}$, respectively, at $\mathrm{d} 28$. This inhibiting effect of salt on methylbutyric acid formation was observed regardless of PAB strain, but the intensity of the inhibition was strain-dependent. The effect of PAB strain was therefore determined at each level of salt. Significant $(P<0.05)$ differences in the amount of methylbutyric acids were found as function of $\mathrm{PAB}$ strain, both at $1 \%$ and $1.8 \%$ salt-in-moisture (Fig. 3). Some strains showed marked (>60\%) reduction in isovaleric acid production at high salt content (ITGP4, ITGP5, ITGP6, ITGP11, ITGP16, ITGP20), whereas other strains showed no or weak $(<10 \%)$ reduction (ITGP3, ITGP10, ITGP24, A). Therefore, the profile of strain classification for their isovaleric acid production showed marked differences at the two salt levels. The two strains producing the highest amounts at $1.0 \%$ salt-in-moisture (ITGP12 and ITGP13), however, also produced high amounts at $1.8 \%$ salt-in-moisture (Fig. 3). The inhibition of isovaleric acid production by salt was not related to the inhibition of propionic
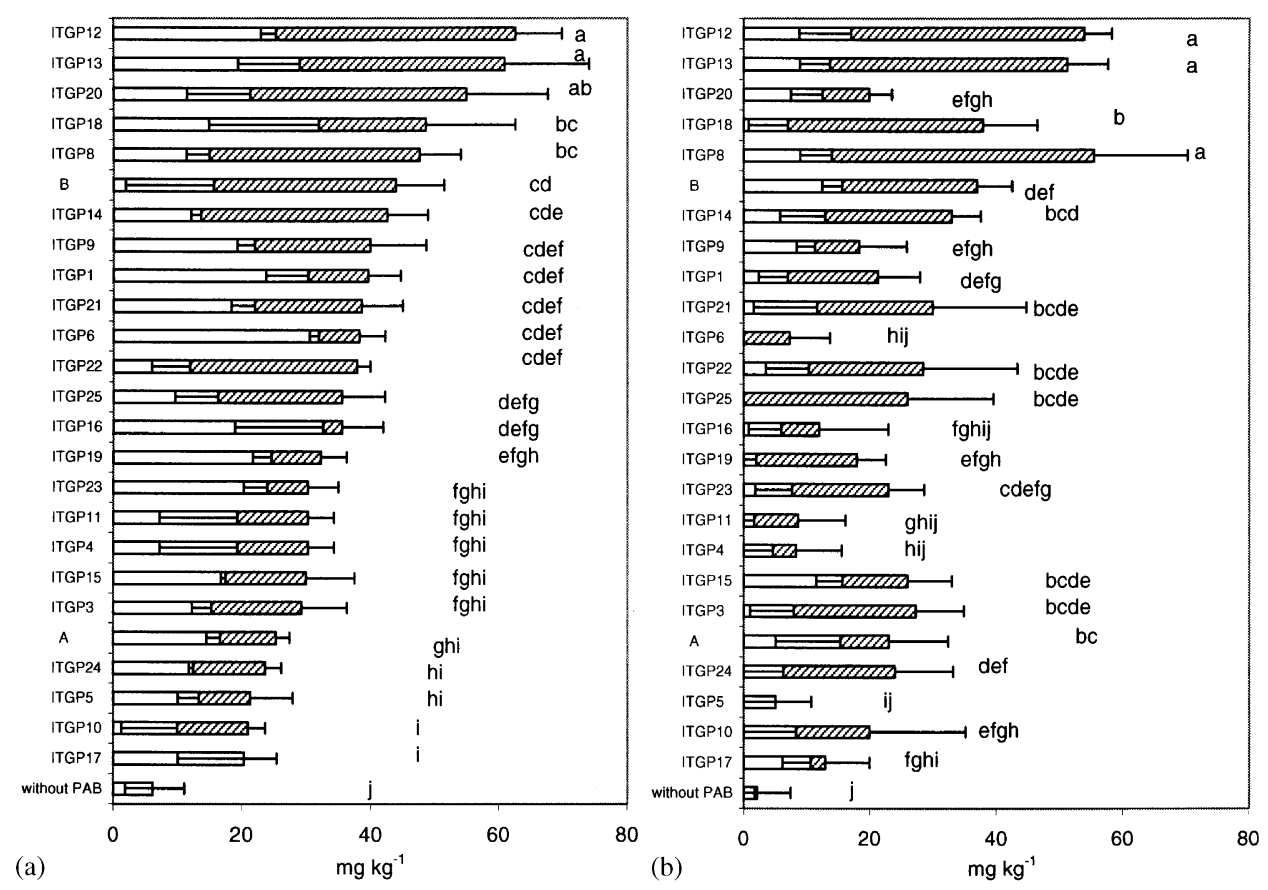

Fig. 3. Effect of the $P$. freudenreichii strain on the production of methylbutyric acids in mini Swiss cheeses at two stages of ripening in the warm room ( $\square$, at d 14; 西, from d15 to d28), at two salt-in-moisture levels (a: $1 \%$; b: $1.8 \%$ ). The same strains of thermophilic lactic starter were used for all the cheeses. Labels and error-bars show the means and standard deviations of triplicate cheeses. Values with the same letter do not significantly differ according to the LSD test $(P<0.05)$. 
fermentation (evaluated by the production of propionic acid at d14). For instance, ITGP6 produced $64 \%$ isovaleric acid less, but only $16 \%$ propionic acid less at $1.8 \%$ salt-in-moisture than at $1 \%$, whereas, on the contrary, ITGP 3 produced only $7 \%$ isovaleric acid less, but $51 \%$ propionic acid less.

\section{Discussion}

This study showed that methylbutyric acids were mainly produced by $\mathrm{PAB}$ in our controlled-microflora Swiss cheeses, and confirms with 25 PAB strains and several lactic starter strains, the results observed with one PAB strain in the same type of experimental cheeses (Thierry et al., 2002). In the presence of PAB, the quantity of methylbutyric acids was three to ten times greater, depending on PAB strain, than in the absence of PAB. The strain of PAB significantly $(P<0.05)$ affected the quantity of methylbutyric acids produced. The values of methylbutyric acid concentrations in our experimental cheeses $\left(37 \mathrm{mg} \mathrm{kg}^{-1}\right.$ on average at the end of warm room ripening) were close to the values previously reported for Swiss cheese $\left(25-30 \mathrm{mg} \mathrm{kg}^{-1}\right.$ in French Emmental cheese and in Comté cheese (Berdagué et al., 1987, 1990)). Thermophilic lactic acid bacteria alone produced only small amounts of methylbutyric acids $\left(<6 \mathrm{mg} \mathrm{kg}^{-1}\right)$, regardless of the species and strains constituting the lactic starter. These values are comparable to the ones observed in some internally ripened cheeses without PAB: $0.5-5 \mathrm{mg} \mathrm{kg}^{-1}$ in Gouda cheese (Yvon, Berthelot, \& Gripon, 1998), $0-0.13 \mathrm{mg} \mathrm{kg}^{-1}$ in Manchego cheese (Villasenor, Valero, Sanz, \& Martinez-Castro, 2000), normally under detection in Cheddar cheese (Patton, 1964; McSweeney et al., 1997). In contrast to our results, in Swiss cheeses manufactured with different combinations of $S$. thermophilus, L. helveticus, and P. freudenreichii, some authors observed high concentrations of methylbutyric acids even in the absence of PAB (Paulsen, Kowalewska, Hammond, \& Glatz, 1980). However, the contaminating microflora that reached high counts in these cheeses could have produced methylbutyric acids. Although the experiments analysed in the present study were not initially designed to calculate the interactions between the lactic starters and $\mathrm{PAB}$, no significant differences were found for the content of methylbutyric acids within groups of cheeses containing the same PAB strain and different lactic starters (Fig. 1). This result lets us think that the possible interactions between the lactic starters and $\mathrm{PAB}$ have a minor effect on the production of methylbutyric acids compared to the effect of $\mathrm{PAB}$ strain.

The technology of mini-Swiss cheese manufacture that we used limited the possible contamination by nonstarter lactic acid bacteria (NSLAB), which counts were
$<10^{6} \mathrm{cfu} \mathrm{g}^{-1}$ at the end of ripening, as previously observed in mini cheeses manufactured using the same cheese-making process (Valence, Deutsch, Richoux, Gagnaire, \& Lortal, 2000; Hervé, 2000). No conclusions can therefore be drawn from the present study in relation to their possible contribution to the production of methylbutyric acids in Swiss cheese. However, NSLAB grow at numbers as high as $5 \times 10^{8} \mathrm{cfu} \mathrm{g}^{-1}$ cheese during ripening in commercial Swiss cheeses. As NSLAB are able to convert leucine into isovaleric acid in vitro (Nakae \& Elliot, 1965; Tammam et al., 2000; Williams et al., 2001; Tavaria et al., 2002), they could also contribute to methylbutyric acid production in Swiss cheeses. Two factors lead us to believe that the contribution of NSLAB is low compared to that of PAB. First, the values of isovaleric acid concentrations in our experimental cheeses were close to the values previously reported for Swiss cheese (Langler \& Day, 1966; Bosset et al., 1992). Moreover, only very small amounts of isovaleric acid were found in full-size Swiss cheeses containing NSLAB but no PAB (Kerjean, personal communication).

Our cheese-making experiments did not make it possible to make cheeses with PAB starters alone, without lactic starters, which would have shown the activity of $\mathrm{PAB}$ in the absence of lactic acid bacteria. Therefore, we can only conclude that PAB are involved in at least one limiting step of methylbutyric acid formation. The pathway of isovaleric formation from branched-chain amino acids by cheese bacteria was recently brought to light. After a first step of transamination of leucine (or isoleucine), the $\alpha$-ketoacid formed is decarboxylated and oxidised in one or several steps to 3-methylbutyric (isovaleric) acid (or 2-methylbutyric acid from isoleucine). The oxidation step requires the presence of metabolically active cells capable to reoxidise the necessary cofactors. As thermophilic lactic acid bacteria lyse early during Swiss-cheese ripening (Valence, Richoux, Thierry, Palva, \& Lortal, 1998; Deutsch, Ferain, Delcour, \& Lortal, 2002), they influence cheese ripening through the activity of the intracellular enzymes that they release by lysis, such as peptidases. However, it is likely that the involvement of thermophilic lactic acid bacteria in oxidation reactions is limited. These species could nevertheless be involved in the first step of leucine/isoleucine catabolism.

Sensory evaluations are now necessary to determine the impact of differences in content of methylbutyric acid in Swiss cheese.

\section{Acknowledgements}

Part of this work was supported by grants from the Regional Council of Brittany. 


\section{References}

Berdagué, J. L., \& Grappin, R. (1988). Affinage et qualité du gruyère de Comté VI Caractéristiques sensorielles des fromages. Le Lait, 68, 189-204.

Berdagué, J. L., Grappin, R., Delacroix-Buchet, A., \& Chaillet, B. (1990). Caractéristique de l'emmental "Grand-Cru" français. I. Composition physico-chimique. Le Lait, 70, 1-14.

Berdagué, J. L., Jeunet, R., \& Grappin, R. (1987). Affinage et qualité du Gruyère de Comté III Fermentation lactique et teneur en acides gras volatils des fromages de Comté. Le Lait, 67, 249-263.

Biede, S. L., Paulsen, P. V., Hammond, E. G., \& Glatz, B. A. (1979). The flavor of Swiss Cheese. In U. La (Ed.), Developments in industrial microbiology (pp. 203-210). Arlington, VA: Society for Industrial Microbiology.

Bosset, J. O., Collomb, M., Grand, M., Lavanchy, P., Kaufmann, E., \& Kreuter, U. (1992). Application de méthodes d'analyse statistique univariée et multivariée à l'étude parallèle de critères chimiques, biochimiques, rhéologiques, microbiologiques et sensoriels du fromage d'emmental au moment de sa taxation. Partie I: Analyse de quelques profils de distribution. Chimia, 46, 406-415.

Bugaud, C., Buchin, S., Hauwuy, A., \& Coulon, J. B. (2001). Relationships between flavour and chemical composition of Abondance cheese derived from different types of pastures. Le Lait, 81, 757-773.

Deutsch, S. M., Ferain, T., Delcour, J., \& Lortal, S. (2002). Lysis of lysogenic strains of Lactobacillus helveticus in Swiss cheeses and first evidence of concomitant Streptococcus thermophilus lysis. International Dairy Journal, 12, 591-600.

Helinck, S., Moreau, D., \& Yvon, M. (2001). Thermophilic lactobacilli have high ability to produce aroma compounds from leucine. Poster abstract P37, NIZO Dairy Conference on Food Microbes 2001, Ede, Netherland.

Hervé, C. (2000). Démonstration et étude de la lysogénie de Propionibacterium freudenreichii subsp. shermanii. Ph.D. of ENSAR Rennes, France, pp.151.

Isolini, D., Grand, M., \& Glättli, H. (1990). Selektivmedien zum Nachweis von obligat und fakultativ heterofermentativen Laktobazillen. Schweizerische Milchwirtschaftliche Forschung, 19, 57-59.

Langler, J. E., \& Day, E. A. (1966). Quantitative analysis of the major free fatty acids in Swiss cheese. Journal of Dairy Science, 49, 91-93.

Langler, J. E., Libbey, L. M., \& Day, E. A. (1967). Identification and evaluation of selected compounds in Swiss cheese flavor. Journal of Agricultural and Food Chemistry, 14, 386-396.

Malik, A. C., Reinbold, G. W., \& Vedamuthu, E. R. (1968). An evaluation of the taxonomy of Propionibacterium. Canadian Journal of Microbiology, 14, 1185-1191.

McSweeney, P. L. H., Nursten, H. E., \& Urbach, G. (1997). Flavours and off-flavours in milk and dairy products. In P. F. Fox (Ed.), Advanced Dairy Chemistry, Lactose, Water, Salts and Vitamins (pp. 403-468). London: Chapman \& Hall.

Nakae, T., \& Elliot, J. A. (1965). Production of volatile fatty acids by some lactic acid bacteria. II. Selective formation of volatile fatty acids by degradation of amino acids. Journal of Dairy Science, 48 , 293-299.
Patton, S. (1964). Volatile acids of Swiss cheese. Journal of Dairy Science, 47, 817-818.

Paulsen, P. V., Kowalewska, J., Hammond, E. G., \& Glatz, B. A. (1980). Role of microflora in production of free fatty acids and flavor in Swiss cheese. Journal of Dairy Science, 63, 912-918.

Preininger, M., Warmke, R., \& Grosch, W. (1996). Identification of the character impact flavour compounds of Swiss cheese by sensory studies of models. Zeitschrift für Lebensmittel-Untersuchung undForschung, 202, 30-34.

Richoux, R., Faivre, E., \& Kerjean, J. R. (1998). Effet de la teneur en $\mathrm{NaCl}$ sur la fermentation du lactate par Propionibacterium freudenreichii dans des minifromages à pâte cuite. Le Lait, 78 , 319-331.

Richoux, R., \& Kerjean, J. R. (1995). Caractérisation technologique de souches pures de bactéries propioniques: test en minifabrication de fromages à pâte cuite. Le Lait, 75, 45-59.

Tammam, J. D., Williams, A. G., Noble, J., \& Lloyd, D. (2000). Amino acid fermentation in nonstarter Lactobacillus spp. isolated from Cheddar cheese. Letters in Applied Microbiology, 30, 370-374.

Tavaria, F. K., Dahl, S., Carballo, F. J., \& Malcata, F. X. (2002) Amino acid catabolism and generation of volatiles by lactic acid bacteria. Journal of Dairy Science, 85, 2462-2470.

Thierry, A., \& Maillard, M. B. (2002). Production of cheese flavour compounds derived from amino acid catabolism by Propionibacterium freudenreichii. Le Lait, 82, 17-32.

Thierry, A., Maillard, M. B., \& Yvon, M. (2002). Conversion of L-leucine to isovaleric acid by Propionibacterium freudenreichii TL 34 and ITGP23. Applied and Environmental Microbiology, 68, 608-615.

Thierry, A., Salvat-Brunaud, D., \& Maubois, J. L. (1999). Influence of thermophilic lactic acid bacteria strains on propionibacteria growth and lactate consumption in an Emmental juice-like medium. Journal of Dairy Research, 66, 105-113.

Valence, F., Deutsch, S. M., Richoux, R., Gagnaire, V., \& Lortal, S. (2000). Autolysis and related proteolysis in Swiss cheese for two Lactobacillus helveticus strains. Journal of Dairy Research, 67, 261-271.

Valence, F., Richoux, R., Thierry, A., Palva, A., \& Lortal, S. (1998) Autolysis of Lactobacillus helveticus and Propionibacterium freudenreichii in Swiss cheeses: First evidence by using species-specific lysis markers. Journal of Dairy Research, 65, 609-620.

Villasenor, M. J., Valero, E., Sanz, J., \& Martinez-Castro, I. (2000). Analysis of volatile components of Manchego cheese by dynamic headspace followed by automatic thermal desorption-GC-MS. Milchwissenschaft, 55, 378-382.

Williams, A. G., Noble, J., \& Banks, J. M. (2001). Catabolism of amino acids by lactic acid bacteria isolated from Cheddar cheese. International Dairy Journal, 11, 203-215.

Yvon, M., Berthelot, S., \& Gripon, J. C. (1998). Adding alphaketoglutarate to semi-hard cheese curd highly enhances the conversion of amino acids to aroma compounds. International Dairy Journal, 8, 889-898.

Yvon, M., \& Rijnen, L. (2001). Cheese flavour formation by amino acid catabolism. International Dairy Journal, 11, 185-201. 